\title{
Evaluation of Sweetcorn Hybrids under Varying Planting Density and Nutrient Levels
}

\author{
A.P. Sivamurugan, R. Ravikesavan, C. Bharathi ${ }^{1}$
}

10.18805/ag.D-5465

\begin{abstract}
Background: Productivity of sweet corn depends on genetic makeup and adoption of innovative technological interventions viz., planting density, balanced application of organic manures and fertilizers, herbicides etc. Nevertheless, the response to the aforementioned interventions may vary with different locations owing to varied climatic and edaphic and other management factors. Enhancement in productivity can be achieved through adoption of proper planting density and nutrient management as they play a vital role. The present study aimed to evaluate different sweet corn hybrids under varied planting density and nutrient levels for improving the productivity of sweetcorn.

Methods: Field experiments were conducted during Kharif, 2019 and Kharif, 2020 to evaluate sweet corn hybrids under varying planting density and nutrient levels. The experiments were laid out in a split split plot design. In the main plot, two sweet corn hybrids and in the sub plot, two planting densities and in the sub sub plot, three nutrient levels were tried. Observations on growth, green cob yield and green fodder yield were recorded.

Result: Based on the results of two years of experimentation, it is concluded that MISTHI recorded higher green cob yield (16330 kg ha $^{-1}$ ), net return (Rs. 64931/ha) and BC ratio (2.47) under $60 \times 15 \mathrm{~cm}$ with 100\% RDF (120:60:45 NPK kg/ha). CSCH-15001 recorded relatively lower green cob yield (15649 $\mathrm{kg} \mathrm{ha}^{-1}$ ), net return (Rs. 61291/ha) and B:C ratio (2.38) under $60 \times 15 \mathrm{~cm}$ with $100 \%$ RDF.

Key words: Nutrient levels, Planting density, Sweet corn, Yield.
\end{abstract}

\section{INTRODUCTION}

Sweet corn is one of the most promising vegetables in the developed countries of the world. In India, it is becoming popular among the peri-urban farmers due to high market potential in urban areas. It has high sugar content of $16-$ $18 \%$ (Znidarcic,2012) and is a rich source of carbohydrate, vitamin $C$, niacin, thiamine and vitamin $A$ and has significant amount of dietary fibre and potassium (Erdal et al.,2011 and Santos et al.,2014). It is highly delicious and the green cobs are eaten as raw, boiled or steamed or used in the preparation of soup, salad and other recipes and the stover after harvest of cobs is used as a green fodder for milch animals.

Yield potential of sweet corn is mainly based on its genetic makeup and the environment where it grows. Nevertheless, maximum genetic potential can be exploited through congenial environment as the yield is interactive product of genotype, management and environmental factors. Agro techniques or management factors viz., tillage, planting density, irrigation, weed management, nutrient management and pest and disease management are recommended for adoption to improve the productivity of sweet corn. However, responses to these aforementioned practices vary across environments. Among them, planting density and nutrient management plays an important role in enhancing the productivity of sweet corn. The yield of a crop is decided based on planting density as it directly affects the yield attributes and yield (Oktem and Oktem, 2005). Optimum planting density ensures effective utilization of land, water, nutrients and other resources resulting in better growth and development of crops. Sweet corn removes large
Department of Millets, Tamil Nadu Agricultural University, Coimbatore-641 003, Tamil Nadu, India.

1Department of Agronomy, Tamil Nadu Agricultural University, Coimbatore-641 003, Tamil Nadu, India.

Corresponding Author: A.P. Sivamurugan, Department of Millets, Tamil Nadu Agricultural University, Coimbatore-641 003, Tamil Nadu, India. Email: apacsivamurugan@gmail.com

How to cite this article: Sivamurugan, A.P., Ravikesavan, R. and Bharathi, C. (2022). Evaluation of Sweetcorn Hybrids under Varying Planting Density and Nutrient Levels. Agricultural Science Digest. DOI: 10.18805/ag.D-5465.

Submitted: 30-07-2021 Accepted: 04-01-2022 Online: 19-02-2022

quantities of nutrients especially nitrogen, phosphorus and potassium from soil for the growth. Remarkable reduction in yield is observed when the supply of nitrogen is suboptimal from the soil as other nutrients are not absorbed and translocated properly by the plants (Haque et al., 2001). Hence, balanced application of nitrogen, phosphorus and potassium plays a vital role in increasing the yield of sweet corn. Keeping in view the above facts, the present experimentation was conducted to evaluate sweet corn hybrids under varying planting density and nutrient levels.

\section{MATERIALS AND METHODS}

Field experiments were carried out at Department of Millets, Tamil Nadu Agricultural University, Coimbatore during Kharif, 2019 and Kharif, 2020 to evaluate sweet corn hybrids under varying planting density and nutrient levels. The 
experimental site is located at $11^{\circ} \mathrm{N}$ latitude, $77^{\circ} \mathrm{E}$ longitude and at an altitude of $426.7 \mathrm{~m}$ above the MSL. The soil was sandy clay loam and low in available $\mathrm{N}$, medium in available $\mathrm{P}$ and high in available $\mathrm{K}$. During the cropping period, a total rainfall of $135.5 \mathrm{~mm}$ was received in 12 rainy days. The mean maximum and minimum temperatures were $30.8^{\circ} \mathrm{C}$ and $21.3^{\circ} \mathrm{C}$, respectively. Relative humidity ranged from 71 to 86 and 32 to 48 per cent during forenoon and afternoon, respectively. The experiments were laid out in a split split plot design. In the main plot, two sweet corn hybrids viz., $\mathrm{H}_{1}-\mathrm{CSCH}$ - 15001 and $\mathrm{H}_{2}$ - MISTHI and in the sub plot, two planting densities viz., $D_{1}-60 \times 20 \mathrm{~cm}$ and $D_{2}-60 \times 15 \mathrm{~cm}$ and in the sub sub plot, three nutrient levels viz., $\mathrm{N}_{1}-100 \%$ RDF (120:60:45 NPK kg/ha), $\mathrm{N}_{2}-90 \%$ RDF (108:54:41 NPK kg/ha) and $\mathrm{N}_{3}-80 \%$ RDF (96:48:36 NPK kg/ha) were tried in three replications in both the years. Observations on plant height at harvest, green cob yield, green fodder yield, TSS, nutrient uptake, soil available NPK were recorded.

\section{RESULTS AND DISCUSSION}

Plant height, green cob yield, green fodder yield and TSS

The data on plant height, yield and TSS are given in Table 1. Experimental results revealed that the sweet corn hybrids exerted significant influence on plant height at harvest during Kharif, 2019. Among the hybrids, MISTHI $\left(\mathrm{H}_{2}\right)$ recorded higher plant height of $192.1 \mathrm{~cm}$ at harvest which was significantly superior to $\mathrm{H}_{1}(\mathrm{CSCH}-15001)$. The hybrids did not evince significant effect on plant height at harvest during Kharif, 2020. Planting densities and nutrient levels failed to exert significant influence on plant height at harvest in both the years. Nevertheless, $D_{2}(60 \times 15 \mathrm{~cm})$ recorded higher plant height of $186.9 \mathrm{~cm}$ and $216.8 \mathrm{~cm}$ during Kharif, 2019 and Kharif, 2020,respectively. This was ascribed to more competition for space, light, nutrients and other resources which favoured higher plant height under high density. The results are in accordance with the findings of Mathukia et al., 2014 and Nandeha et al.,2016.In respect of nutrient levels, $N_{1}(100 \% R D F)$ recorded higher recorded higher plant height of $189.5 \mathrm{~cm}$ and $219.2 \mathrm{~cm}$ during Kharif, 2019 and Kharif, 2020,respectively. This might be due to higher availability of nutrients leading to prolonged vegetative growth thus favoured plant height. These results confirm with those findings of Singh et al., 2019, Kumar et al., 2007 who reported that plant height increased with enhanced level of NPK application. The interaction effect was not significant.

Though MISTHI $\left(\mathrm{H}_{2}\right)$ recorded higher green cob yield of $13905 \mathrm{~kg} \mathrm{ha}^{-1}$ and $14663 \mathrm{~kg} \mathrm{ha}^{-1}$ during Kharif, 2019 and Kharif, 2020, respectively there was no significant influence on green cob yield among the hybrids in both the years. With respect to planting density, $\mathrm{D}_{2}(60 \times 15 \mathrm{~cm})$ recorded higher green cob yield of $14745 \mathrm{~kg} \mathrm{ha}^{-1}$ and $15651 \mathrm{~kg} \mathrm{ha}^{-1}$ during Kharif, 2019 and Kharif, 2020, respectively. This was significantly superior to $D_{1}(60 \times 20 \mathrm{~cm})$. This might be due to higher dry matter production through effective utilization of space, light, nutrients etc. under high density compared to low density as the yield directly depends on plant population. The results confirm the findings of Massey and Gaur, 2013, Dangariya et al., 2017 and Kumar and Chawla, 2018. In respect of nutrient levels, $N_{1}(100 \% R D F)$ recorded higher yield of $14295 \mathrm{~kg} \mathrm{ha}^{-1}$ during Kharif, 2019 which was comparable with $90 \%$ RDF but was superior to $80 \%$ RDF. In Kharif 2020 , also $\mathrm{N}_{1}(100 \% \mathrm{RDF})$ recorded higher yield of $15130 \mathrm{~kg} \mathrm{ha}^{-1}$ which was comparable with $90 \%$ RDF but was superior to $80 \%$ RDF. The increased yield with $100 \%$ RDF might be due to improved absorption and translocation of nutrients through better root establishment thus favouring more production of chlorophyll in plants. This facilitated the utilization of more solar energy for production of carbohydrates. Better availability of photosynthates improved length, girth of cob and test weight of grain resulting in higher yield. The results are in accordance with the findings of Akhtar and Silva,1999, Grazia et al., 2003, Singh et al., 2003, Sonbai et al., 2013, Dangariya et al., 2017 and Rao et al., 2020. The interaction was found to be non-significant.

Green fodder yield was not significantly influenced by the hybrids. Nevertheless, $\mathrm{H}_{1}(\mathrm{CSCH}-15001)$ recorded higher green fodder yield of $9855 \mathrm{~kg} \mathrm{ha}^{-1}$ and $10210 \mathrm{~kg} \mathrm{ha}^{-1}$ during Kharif, 2019 and Kharif, 2020, respectively. Among the planting densities, $D_{2}(60 \times 15 \mathrm{~cm})$ recorded higher green fodder yield of $10393 \mathrm{~kg} \mathrm{ha}^{-1}$ and $10768 \mathrm{~kg} \mathrm{ha}^{-1}$ during Kharif, 2019 and Kharif, 2020, respectively. This was significantly superior to $D_{1}(60 \times 20 \mathrm{~cm})$. This was ascribed to higher biomass accumulation by utilizing the natural resources effectively under high density. The results confirm the findings of Sunitha and Reddy (2012), Mathukia et al.(2014) and Kumar and Narayan(2018).W ith respect to nutrient levels, $\mathrm{N}_{1}(100 \% \mathrm{RDF})$ recorded higher yield of $10644 \mathrm{~kg} \mathrm{ha}$ ${ }^{1}$ during Kharif, 2019 which was comparable with $90 \%$ RDF but was superior to $80 \%$ RDF. During Kharif, 2020, also $\mathrm{N}_{1}\left(100 \%\right.$ RDF) recorded higher yield of $10916 \mathrm{~kg} \mathrm{ha}^{-1}$ which was comparable with $90 \%$ RDF but was superior to $80 \%$ RDF. The increased green fodder yield with the application of $100 \%$ RDF might be due to the development of extensive root system, which favoured more absorption and translocation of nutrients thus enhanced photosynthetic activity, high rate of assimilation, better growth and development. The results are in accordance with the findings of Massey and Gaur (2013), Kumar and Chawla,(2018) and Singh,(2019). The interaction effect was not significant. None of the treatments evinced significant influence on TSS.

\section{Nutrient uptake}

The data on nutrient uptake in grain and stover are given in Table 2 . The results revealed that planting density and nutrient levels exerted significant influence on nitrogen, phosphorus and potassium uptake in grain and stover. Among the hybrids, MISTHI $\left(\mathrm{H}_{2}\right)$ recorded higher nitrogen uptake of $62.6 \mathrm{~kg} \mathrm{ha}^{-1}$ and $66.1 \mathrm{~kg} \mathrm{ha}^{-1}$ in grain during Kharif, 2019 and Kharif, 2020, respectively which were significantly superior to $H_{1}$. With respect to planting density, $D_{2}(60 \times 15 \mathrm{~cm})$ 
Evaluation of Sweetcorn Hybrids under Varying Planting Density and Nutrient Levels

Table 1: Effect of planting density and nutrient levels on plant height, green cob yield, green fodder yield and TSS.

\begin{tabular}{|c|c|c|c|c|c|c|c|c|}
\hline \multirow{2}{*}{ Treatments } & \multicolumn{2}{|c|}{ Plant height at harvest $(\mathrm{cm})$} & \multicolumn{2}{|c|}{ Green cob yield $(\mathrm{kg} / \mathrm{ha})$} & \multicolumn{2}{|c|}{ Green fodder yield (kg/ha) } & \multicolumn{2}{|c|}{ TSS (\%) } \\
\hline & Kharif, 2019 & Kharif, 2020 & Kharif, 2019 & Kharif, 2020 & Kharif, 2019 & Kharif, 2020 & Kharif, 2019 & Kharif, $202 C$ \\
\hline \multicolumn{9}{|l|}{ Main plot } \\
\hline $\mathrm{H}_{1}$ & 178.8 & 211.6 & 13324 & 14009 & 9855 & 10210 & 17.6 & 15.9 \\
\hline $\mathrm{H}_{2}$ & 192.1 & 219.2 & 13905 & 14663 & 9432 & 9872 & 18.6 & 16.3 \\
\hline SEd & 2.3 & 4.1 & 276 & 294 & 171 & 218 & 1.14 & 1.19 \\
\hline$C D(p=0.05)$ & 7.1 & NS & NS & NS & NS & NS & NS & NS \\
\hline \multicolumn{9}{|l|}{ Sub plot } \\
\hline $\mathrm{D}_{1}$ & 184.1 & 213.9 & 12484 & 13021 & 8893 & 9315 & 18.7 & 16.1 \\
\hline $\mathrm{D}_{2}$ & 186.9 & 216.8 & 14745 & 15651 & 10393 & 10768 & 17.4 & 16.0 \\
\hline SEd & 2.6 & 2.3 & 233 & 257 & 249 & 168 & 1.31 & 1.42 \\
\hline$C D(p=0.05)$ & NS & NS & 647 & 714 & 692 & 467 & NS & NS \\
\hline \multicolumn{9}{|l|}{ Sub sub plot } \\
\hline $\mathrm{N}_{1}$ & 189.5 & 219.2 & 14295 & 15130 & 10644 & 10916 & 17.7 & 16.1 \\
\hline $\mathrm{N}_{2}$ & 185.6 & 215.7 & 13678 & 14471 & 9752 & 10184 & 18.0 & 16.0 \\
\hline $\mathrm{N}_{3}$ & 181.3 & 211.3 & 12872 & 13407 & 8534 & 9023 & 18.6 & 16.1 \\
\hline SEd & 7.4 & 4.6 & 289 & 331 & 427 & 374 & 1.46 & 1.59 \\
\hline$C D(p=0.05)$ & NS & NS & 635 & 702 & 906 & 792 & NS & NS \\
\hline
\end{tabular}

Table 2: Effect of planting density and nutrient levels on NPK uptake in grain and stover.

\begin{tabular}{|c|c|c|c|c|c|c|c|c|c|c|c|c|}
\hline \multirow{3}{*}{ Treatments } & \multicolumn{4}{|c|}{$\mathrm{N}$ uptake $(\mathrm{kg} / \mathrm{ha})$} & \multicolumn{4}{|c|}{$P$ uptake $(\mathrm{kg} / \mathrm{ha})$} & \multicolumn{4}{|c|}{ K uptake (kg/ha) } \\
\hline & \multicolumn{2}{|c|}{ Grain } & \multicolumn{2}{|c|}{ Stover } & \multicolumn{2}{|c|}{ Grain } & \multicolumn{2}{|c|}{ Stover } & \multicolumn{2}{|c|}{ Grain } & \multicolumn{2}{|c|}{ Stover } \\
\hline & $\begin{array}{c}\text { Kharif, } \\
2019\end{array}$ & $\begin{array}{c}\text { Kharif, } \\
2020\end{array}$ & $\begin{array}{c}\text { Kharif, } \\
2019\end{array}$ & $\begin{array}{c}\text { Kharif, } \\
2020\end{array}$ & $\begin{array}{c}\text { Kharif, } \\
2019\end{array}$ & $\begin{array}{c}\text { Kharif, } \\
2020\end{array}$ & $\begin{array}{c}\text { Kharif, } \\
2019\end{array}$ & $\begin{array}{c}\text { Kharif, } \\
2020\end{array}$ & $\begin{array}{c}\text { Kharif, } \\
2019\end{array}$ & $\begin{array}{c}\text { Kharif, } \\
2020\end{array}$ & $\begin{array}{c}\text { Kharif, } \\
2019\end{array}$ & $\begin{array}{c}\text { Kharif, } \\
2020\end{array}$ \\
\hline \multicolumn{13}{|l|}{ Main plot } \\
\hline $\mathrm{H}_{1}$ & 58.0 & 61.6 & 61.2 & 63.8 & 20.1 & 20.3 & 26.2 & 28.1 & 32.1 & 33.1 & 104.9 & 102.3 \\
\hline $\mathrm{H}_{2}$ & 62.6 & 66.1 & 60.3 & 61.5 & 23.0 & 23.6 & 25.9 & 27.5 & 33.9 & 34.7 & 100.6 & 99.4 \\
\hline SEd & 0.66 & 0.73 & 0.54 & 0.62 & 0.64 & 0.91 & 1.07 & 1.18 & 0.43 & 0.54 & 1.14 & 1.38 \\
\hline$C D(p=0.05)$ & 2.82 & 3.14 & NS & NS & NS & NS & NS & NS & NS & NS & NS & NS \\
\hline \multicolumn{13}{|l|}{ Sub plot } \\
\hline$D_{1}: 60 \times 20 \mathrm{~cm}$ & 55.8 & 58.4 & 56.7 & 59.7 & 19.4 & 19.7 & 24.7 & 26.7 & 30.8 & 31.4 & 94.9 & 94.0 \\
\hline $\mathrm{D}_{2}: 60 \times 15 \mathrm{~cm}$ & 64.7 & 69.2 & 64.8 & 67.5 & 22.6 & 23.3 & 27.5 & 28.9 & 35.2 & 36.3 & 109.6 & 106.8 \\
\hline SEd & 1.07 & 1.28 & 1.05 & 1.15 & 1.17 & 1.39 & 0.71 & 0.80 & 0.60 & 0.64 & 1.78 & 2.25 \\
\hline$C D(p=0.05)$ & 2.98 & 3.55 & 2.92 & 3.21 & NS & NS & 1.97 & 2.13 & 1.68 & 1.77 & 4.96 & 6.24 \\
\hline \multicolumn{13}{|l|}{ Sub sub plot } \\
\hline $\mathrm{N}_{1}: 100 \% \mathrm{RDF}$ & 65.2 & 69.1 & 68.6 & 70.6 & 22.7 & 23.4 & 29.9 & 32.1 & 35.4 & 36.9 & 114.8 & 111.0 \\
\hline $\mathrm{N}_{2}: 90 \% \mathrm{RDF}$ & 60.9 & 64.9 & 61.5 & 64.7 & 21.1 & 21.6 & 26.4 & 27.9 & 33.1 & 33.8 & 103.3 & 102.2 \\
\hline $\mathrm{N}_{3}: 80 \% \mathrm{RDF}$ & 54.8 & 57.4 & 52.2 & 55.6 & 19.4 & 19.2 & 21.9 & 23.2 & 30.6 & 30.7 & 88.9 & 87.9 \\
\hline SEd & 2.16 & 2.40 & 1.99 & 2.98 & 0.86 & 0.95 & 1.76 & 1.95 & 1.22 & 1.48 & 5.57 & 4.29 \\
\hline$C D(p=0.05)$ & 4.57 & 5.09 & 4.21 & 6.32 & 1.83 & 2.01 & 3.72 & 4.24 & 2.59 & 3.23 & 11.8 & 9.10 \\
\hline
\end{tabular}

recorded higher nitrogen uptake of $64.7 \mathrm{~kg} \mathrm{ha}^{-1}$ and $69.2 \mathrm{~kg}$ ha $^{-1}$ in grain during Kharif,2019 and Kharif, 2020, respectively which were significantly superior to $D_{1}$. This was ascribed to more plant population under high density which favoured more nutrient uptake. The results confirm the findings of Bharud et al., 2014. In respect of nutrient levels, $N_{1}$ (100\%RDF) recorded higher nitrogen uptake of $65.2 \mathrm{~kg} \mathrm{ha}^{-1}$ and $69.1 \mathrm{~kg} \mathrm{ha}^{-1}$ in grain during Kharif, 2019 and Kharif,2020, respectively. This was comparable with $90 \%$ RDF but was superior to $80 \%$ RDF. Higher uptake of nutrients with application of $100 \%$ RDF might be due to establishment of extensive root system, which helped in extraction of nutrients from soil and hastened the process of translocation of nutrients to sink thereby improved the nutrient concentration in grain. The results are in conformity with the findings of Akpan and Udoh, (2017) and Kumar and Narayan, (2018).With respect to nitrogen uptake in stover, there was no significant influence among the hybrids. Nevertheless, $\mathrm{H}_{1}(\mathrm{CSCH}-15001)$ recorded higher nitrogen uptake of 61.2 kg ha-1and $63.8 \mathrm{~kg} \mathrm{ha}^{-1}$ during Kharif, 2019 and Kharif, 2020, respectively. Among the planting density, $D_{2}(60 \times 15 \mathrm{~cm})$ recorded higher nitrogen uptake of $64.8 \mathrm{~kg} \mathrm{ha}^{-1}$ and $67.5 \mathrm{~kg}$ 
Evaluation of Sweetcorn Hybrids under Varying Planting Density and Nutrient Levels

Table 3: Effect of planting density and nutrient levels on economics of sweetcorn hybrids.

\begin{tabular}{lcccccc}
\hline \multirow{2}{*}{ Treatments } & \multicolumn{2}{c}{ Green cob yield (kg/ha) } & \multicolumn{2}{c}{ Net return } & Rs./ha) & \multicolumn{2}{c}{ B:C ratio } \\
\cline { 2 - 7 } & Kharif, 2019 & Kharif, 2020 & Kharif, 2019 & Kharif, 2020 & Kharif, 2019 & Kharif, 2020 \\
\hline $\mathrm{H}_{1} \mathrm{D}_{1} \mathrm{~N}_{1}$ & 12871 & 13416 & 45006 & 48545 & 2.06 & 2.15 \\
$\mathrm{H}_{1} \mathrm{D}_{1} \mathrm{~N}_{2}$ & 12257 & 12832 & 40988 & 44855 & 1.98 & 2.07 \\
$\mathrm{H}_{1} \mathrm{D}_{1} \mathrm{~N}_{3}$ & 11462 & 11943 & 35592 & 38945 & 1.86 & 1.94 \\
$\mathrm{H}_{1} \mathrm{D}_{2} \mathrm{~N}_{1}$ & 15134 & 16141 & 58180 & 64402 & 2.31 & 2.45 \\
$\mathrm{H}_{1} \mathrm{D}_{2} \mathrm{~N}_{2}$ & 14513 & 15439 & 53970 & 59890 & 2.23 & 2.37 \\
$\mathrm{H}_{1} \mathrm{D}_{2} \mathrm{~N}_{3}$ & 13706 & 14284 & 48305 & 52214 & 2.12 & 2.21 \\
$\mathrm{H}_{2} \mathrm{D}_{1} \mathrm{~N}_{1}$ & 13446 & 14054 & 48027 & 52026 & 2.13 & 2.23 \\
$\mathrm{H}_{2} \mathrm{D}_{1} \mathrm{~N}_{2}$ & 12837 & 13443 & 44069 & 48200 & 2.06 & 2.15 \\
$\mathrm{H}_{2} \mathrm{D}_{1} \mathrm{~N}_{3}$ & 12034 & 12439 & 38672 & 41638 & 2.94 & 2.01 \\
$\mathrm{H}_{2} \mathrm{D}_{2} \mathrm{~N}_{1}$ & 15728 & 16909 & 61243 & 68618 & 2.38 & 2.55 \\
$\mathrm{H}_{2} \mathrm{D}_{2} \mathrm{~N}_{2}$ & 15103 & 16171 & 57052 & 63916 & 2.30 & 2.46 \\
$\mathrm{H}_{2} \mathrm{D}_{2} \mathrm{~N}_{3}$ & 14285 & 14961 & 51379 & 48545 & 2.18 & 2.15 \\
\hline
\end{tabular}

ha $^{-1}$ in stover during Kharif, 2019 and Kharif, 2020, respectively. This was significantly superior to $D_{1}$ In respect of nutrient levels, $\mathrm{N}_{1}(100 \% \mathrm{RDF})$ recorded higher nitrogen uptake of $68.6 \mathrm{~kg} \mathrm{ha}^{-1}$ in stover during Kharif, 2019 which was significantly superior to $90 \%$ RDF and $80 \%$ RDF. Crop raised in Kharif 2020, $\mathrm{N}_{1}(100 \% \mathrm{RDF})$ recorded higher nitrogen uptake of $70.6 \mathrm{~kg} \mathrm{ha}^{-1}$ in stover which was comparable with $90 \%$ RDF but was superior to $80 \%$ RDF.

With respect to phosphorus uptake in grains, there was no significant influence among the hybrids and planting density. However, MISTHI $\left(\mathrm{H}_{2}\right)$ recorded higher phosphorus uptake of $23.0 \mathrm{~kg} \mathrm{ha}^{-1}$ and $23.6 \mathrm{~kg} \mathrm{ha}^{-1}$ in grain during Kharif, 2019 and Kharif, 2020, respectively. Among the planting density, $D_{2}(60 \times 15 \mathrm{~cm})$ recorded higher phosphorus uptake of $22.6 \mathrm{~kg} \mathrm{ha}^{-1}$ and $23.3 \mathrm{~kg} \mathrm{ha}^{-1}$ in grain during Kharif, 2019 and Kharif, 2020, respectively. This might be due to increase in plant density which influenced the nutrient uptake. Similar view has been expressed by Massey and Gaur, 2013. With regard to nutrient levels, $\mathrm{N}_{1}(100 \% \mathrm{RDF})$ recorded higher phosphorus uptake of $22.7 \mathrm{~kg} \mathrm{ha}^{-1}$ and $23.4 \mathrm{~kg} \mathrm{ha}^{-1}$ in grains during Kharif,2019 and Kharif, 2020, respectively. This was comparable with $90 \%$ RDF but was superior to $80 \%$ RDF. Higher nutrient uptake with the application of $100 \%$ RDF was due to increase in nutrient content of grain and yield. The results are in accordance with the findings of Singh et al., 2009. With respect to phosphorus uptake in stover, there was no significant influence among the hybrids. Nevertheless, $\mathrm{H}_{1}$ (CSCH-15001) recorded higher phosphorus uptake of $26.2 \mathrm{~kg} \mathrm{ha}^{-1}$ and $28.1 \mathrm{~kg} \mathrm{ha}^{-1}$ during Kharif, 2019 and Kharif, 2020, respectively. Among the planting density, $D_{2}(60 \times 15 \mathrm{~cm})$ recorded higher phosphorus uptake of $27.5 \mathrm{~kg} \mathrm{ha}^{-1}$ and $28.9 \mathrm{~kg} \mathrm{ha}^{-1}$ in stover during Kharif, 2019 and Kharif, 2020, respectively. This was significantly superior to $D_{1}$ Among the nutrient levels, $N_{1}$ $(100 \%$ RDF) recorded higher phosphorus uptake of $29.9 \mathrm{~kg}$ ha $^{-1}$ in stover during Kharif, 2019 which was comparable with $90 \%$ RDF but was superior to $80 \%$ RDF. During Kharif 2020, $\mathrm{N}_{1}(100 \% \mathrm{RDF})$ recorded higher phosphorus uptake of 32.1 $\mathrm{kg} \mathrm{ha}^{-1}$ in stover which was comparable with $90 \%$ RDF but was superior to $80 \%$ RDF.

There was no significant influence among the hybrids in respect of potassium uptake in grain. Nevertheless, MISTHI $\left(\mathrm{H}_{2}\right)$ recorded higher potassium uptake of $33.9 \mathrm{~kg}$ $\mathrm{ha}^{-1}$ and $34.7 \mathrm{~kg} \mathrm{ha}^{-1}$ in grain during Kharif, 2019 and Kharif, 2020 , respectively. Among the planting density, $D_{2}(60 \times 15$ $\mathrm{cm})$ recorded higher potassium uptake of $35.2 \mathrm{~kg} \mathrm{ha}^{-1}$ and $36.3 \mathrm{~kg} \mathrm{ha}^{-1}$ in grain during Kharif, 2019 and Kharif, 2020, respectively which were significantly superior to $D_{1}$. Higher nutrient uptake under high density was due to increased number of plants $\mathrm{ha}^{-1}$. The results confirm the findings of Nandeha et al.(2016).Among the nutrient levels, $\mathrm{N}_{1}$ $(100 \% \mathrm{RDF})$ recorded higher potassium uptake of $35.4 \mathrm{~kg}$ $\mathrm{ha}^{-1}$ and $36.9 \mathrm{~kg} \mathrm{ha}^{-1}$ in grain during Kharif, 2019 and Kharif, 2020 , respectively. This was comparable with $90 \%$ RDF but was superior to $80 \%$ RDF. This might be due to improvement in nutrient concentration of grain favoured by inorganic fertilizer application. The results are in accordance with the findings of Rasool et al. (2016).With respect to potassium uptake in stover, there was no significant influence among the hybrids. However, $\mathrm{H}_{1}(\mathrm{CSCH}-15001)$ recorded higher potassium uptake of $104.9 \mathrm{~kg} \mathrm{ha}^{-1}$ and $102.3 \mathrm{~kg} \mathrm{ha}^{-1}$ during Kharif,2019 and Kharif, 2020, respectively. Among the planting density, $D_{2}(60 \times 15 \mathrm{~cm})$ recorded higher potassium uptake of $109.6 \mathrm{~kg} \mathrm{ha}^{-1}$ and $106.8 \mathrm{~kg} \mathrm{ha}^{-1}$ in stover during Kharif, 2019 and Kharif, 2020, respectively. This was significantly superior to $D_{1}$ In respect of nutrient levels, $N_{1}$ $(100 \% \mathrm{RDF})$ recorded higher potassium uptake of $114.8 \mathrm{~kg}$ ha $^{-1}$ and $111 \mathrm{~kg} \mathrm{ha}^{-1}$ during Kharif, 2019 and Kharif, 2020, respectively. This was comparable with $90 \%$ RDF but was superior to $80 \%$ RDF.

\section{Economics}

The data on net return and $\mathrm{B}: \mathrm{C}$ ratio are given in Table 3.During Kharif, 2019, $\mathrm{H}_{2}$ (MISTHI) under $60 \times 15 \mathrm{~cm}$ spacing with 100\% RDF (120:60:45 NPK kg/ha) registered higher net return (Rs. 61243/ha) and $B C$ ratio (2.38). This was followed by $\mathrm{H}_{1}(\mathrm{CSCH}-15001)$ which recorded a net return 
of Rs. $58180 /$ ha and B:C ratio of 2.31 under $60 \times 15 \mathrm{~cm}$ spacing with $100 \%$ RDF. During Kharif 2020, $\mathrm{H}_{2}$ (MISTHI) under $60 \times 15 \mathrm{~cm}$ spacing with 100\% RDF (120:60:45 NPK $\mathrm{kg} / \mathrm{ha}$ ) registered higher net return (Rs. 68618/ha) and BC ratio (2.55). This was followed by $\mathrm{H}_{1}(\mathrm{CSCH}-15001)$ which recorded a net return of Rs. $64402 /$ ha and $B: C$ ratio of 2.45 under $60 \times 15 \mathrm{~cm}$ spacing with $100 \%$ RDF. Lower net return and $\mathrm{BC}$ ratio were registered by $\mathrm{H}_{1}(\mathrm{CSCH}-15001)$ under $60 \times 20 \mathrm{~cm}$ spacing with 80\% RDF (96:48:36 NPK kg/ ha) in both the years.

\section{CONCLUSION}

Based on the results of two years of experimentation, it is concluded that MISTHI recorded higher green cob yield (16330 kg ha-1), net return (Rs. 64931/ha) and BC ratio (2.47) under $60 \times 15 \mathrm{~cm}$ with 100\% RDF (120:60:45 NPK kg/ha). $\mathrm{CSCH}-15001$ recorded relatively lower green cob yield (15649 kg ha-1), net return (Rs. 61291/ha) and BC ratio (2.38) under $60 \times 15 \mathrm{~cm}$ with $100 \%$ RDF.

Conflict of interest: None.

\section{REFERENCES}

Akhtar, M. and Silva, J.A. (1999). Agronomic traits and productivity of sweet corn affected by nitrogen and intercropping. Pakistan Journal of Soil Science. 16(1-2): 49-52.

Akpan, E.A. and Udoh, V.S. (2017). Effects of fertilizer levels on growth and yield attributes of three dwarf sweet corn varieties [Zea mays (L.) Saccharata Strut] in Itu Flood Plain, Akwalbom State, Nigeria. Canadian Journal of Agricultural Crops. 2(1): 60-67.

Bharud, S.R., Bharud, R.W. and Mokate, A.S. (2014). Yield and quality of sweet corn [Zea mays (L.) var. Saccharata] as influenced by planting geometry and fertilizer levels. International Journal of Plant Science. 9(1): 240-243.

Dangariya, M.V., Dudhat, M.S., Bavalgave, V.G. and Thanki, J.D. (2017). Growth, yield and quality of Rabi sweet corn as influenced by different spacing and fertilizer levels. International Journal of Agricultural Science. 13(1): 38-42.

Erdal, S., Pamukcu, M., Savur, O. and Tezel, M. (2011).Evaluation of developed standard sweet corn [Zea mays (L.) sacharata] hybrids for fresh yield, yield component and quality parameters. Turkish Journal of Field Crops. 16(2): 153-156.

Grazia, J.D., Tittonell, P.A., Germinana, D. and Chiesa, A. (2003). Phosphorus and nitrogen fertilization in sweet corn [Zea mays (L.) var. Saccharata Bailey]. Spanish Journal of Agricultural Research. 1(2): 103-107.

Haque, M.M., Hamid, A. and Bhuiyan, N.I. (2001). Nutrient uptake and productivity as affected nitrogen and potassium application levels in maize/sweet potato intercropping system. Crop Science. 46(1): 1-5.

Kumar, A. and Narayan, A. (2018). Influence of planting methods, spacing and fertilization on yield and quality of sweet corn (Zea mays L.). International Journal of Current Microbiology and Applied Science. Special Issue-7: 12321237.
Kumar, M.A.A., Gali, S.K. and Hebsur, N.S. (2007). Effect of different levels of NPK on growth and yield parameters of sweet corn. Karnataka Journal of Agricultural Science 20(1): 41-43.

Kumar, M. and Chawla, J.S. (2018). Evaluation of sweet corn genotypes for green cob and fodder yield under different levels of nutrient and plant spacing. Forage Research. 44(2): 111-114.

Massey, J.X. and Gaur, B.L. (2013). Response of sweet corn cultivars to plant population and fertility levels on yield, NPK uptake and quality characters. International Journal of Agricultural Science. 9(2): 713-715.

Mathukia, R.K., Choudhary, R.P., Shivran, A. and Bhosale, N. (2014). Response of Rabi sweet corn to plant geometry and fertilizer. Current Biotica. 7(4): 294-298.

Nandeha, N., Dewangan, Y. K. and Sahu, P. (2016). Effect of crop geometry and nutrient management on yield performance of Sweet corn [Zea mays (L.) Saccharata] under Chhattisgarh plain ecosystem. The Bioscan. 11(4): 2293-2295.

Oktem, A.G. and Oktem, A. (2005). Effect of Nitrogen and Intra Row Spaces on Sweet Corn [Zea mays (L.) Saccharata Strut] Ear Characteristics. Asian Journal of Plant Science. 4(4): 361-364

Rao, B.M., Mishra, G.C., Mishra, G., Maitra, S. and Adhikari, R. (2020). Effect of integrated nutrient management on production potential and economics in summer sweet corn [Zea mays (L.) var. Saccharata]. International Journal of Chemical Studies. 8(2): 141-144.

Santos, P.H.A.D., Pereira, M.G., Trindade, R.D.S., Cunha, K.S.D., Entringer, G.C. and Vettorazzi, J.C.F. (2014). Agronomic performance of super-sweet corn genotypes in the North of Rio de Janeiro. Crop Breeding and Applied Biotechnology. 14(1): 8-14.

Rasool, S., Hamid, S., Kanth, R.H. and Khan, M.H. (2016). Effect of integrated nutrient management on quality, nutrient content and uptake of sweet corn [Zea mays (L.) Saccharata]. American Journal of Experimental Agriculture. 13(6): 1-11.

Singh, J.K., Bhatnagar, A., Prajapati, B. and Pandey, D. (2019). Influence of integrated nutrient management on the growth, yield and economics of sweet corn (Zea mays saccharata) in spring season. Pantnagar Journal of Research. 17(3): 214-218.

Singh, R.N., Sutaliya, R., Ghatak, R. and Sarangi, S.K. (2003). Effect of higher application of nitrogen and potassium over recommended level on growth, yield and yield attributes of late sown winter maize (Zea mays). Crop Research. 26(1): 71-74.

Sonbai, J.H.H., Prajitno, D. and Syukur, A.(2013).Growth and yield of maize on a various application of nitrogen fertilizer in dry land Regosol. Journal of Agricultural Science. 16(1): 77-89.

Sunitha, N. and Reddy, P.M. (2012). Effect of graded nutrient levels and timing nitrogen application on yield and quality of sweet corn (Zea mays L.). Madras Agricultural Journal. 99(4-6): 240-243.

Znidarcic, D. (2012). Performance and characterization of five sweet corn cultivars as inûuenced by soil properties. Journal of Food Agriculture and Environment. 10(1): 495-500. 